\title{
Evaluation of feeding prickly pear peels to ameliorate the effect of Carbon tetrachloride in rats
}

\author{
Hanady G Sheha and Hoda M El Gezery \\ National Nutrition Institute, Cairo, Egypt.
}

\section{ABSTRACT}

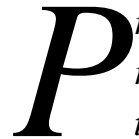

rickly pear peels contain essential compounds such as taurine, amino acids, readily absorbable carbohydrates, minerals, vitamin $C$, flavonoids, tocopherols, and carotenoids. These compounds and derivatives were shown to be endowed with biologically relevant activities including antiinflammatory, antioxidant, hypoglycemic and antimicrobial properties. The present study was designed to investigate some parameters of the chemical composition of prickly pear peels and the effect of their nutritional status on liver and renal injury in rats. Thirty adult male albino rats Sprague-Dawley strain were classified into 2 main groups fed several diets for 28 days as follows: The first negative control group (6 rats / normal group) fed on standard diet. The second group (24rat) injected by carbon tetrachloride $\left(\mathrm{CCl}_{4}\right) ; 6$ rats presented as a positive control group fed on basal diet. 18 rats were as subgroups 1, 2 and 3 fed on basal diet with 5, 10 and $15 \%$ prickly pear peels respectively. At the end of the experimental period (4 week) biological parameters; some biochemical parameters and the histology for liver and renal were evaluated. The results showed a high value of moisture, carbohydrates, protein in prickly pear peels. The positive control group had a significantly lower value of the body weight gain. Liver enzymes and renal parameter of positive control group were higher significantly than negative control group and treated groups. Prickly pear peel ameliorates the effect $\mathrm{CCl}_{4}$ on liver and kidney in rats.

Key wards: prickly pear peel- Liver - kidney - $\mathrm{CCl}_{4}$ 


\section{INTRODUCTION}

Prickly pear also called cactus fruit, cactus figs, Indian figs, Barbary figs, and tunas - are the fruit of the Opuntia cactus plant. Prickly pear peel extract rich in phytosterols showed a hypocholesterolemic effect (Milán-Noris et al., 2016). Yeddes et al ., (2013) illustrated the antioxidant activity and the chemical composition of methanol extracts from peel and pulp belonging to two species of Tunisian prickly pears Opuntia ficus indica (spiny and thornless forms). The peels have higher flavonoids than pulps and the thornless has more flavonoid than the spiny. The analysis detected two classes of phenolic compounds and betalain pigments. Isorhamnetin derivatives are the dominant flavone glycoside identified in $\mathrm{O}$. ficus indicia of peel and pulp of three Tunisian Opuntia forms have been characterized in detail and quantified for the first time. All carotenoids were found to be present in their free form. The main carotenoid in Opuntia peel extracts was lutein. However

Chougui et al., (2015) demonstrated that the margarines elaborated with peel extract were more resistant to oxidation than the margarine reference with vitamin E. Prickly pear peels contain bioactive substances that could be used in different food sectors. Yeddes et al., (2014) showed that $O$. stricta fruits present the best antioxidant activities than the two forms of $\mathrm{O}$. ficus indicia. Other reports suggest that Opuntia ficus-indica has a pharmacological effect in a variety of diseases. Cactus fruit contains substantial amounts of ascorbic acid, vitamin E, carotenoids, fibers, amino acids and antioxidant compounds (phenols, flavonoids, betaxanthin and betacyanin) which have been put forward to account for its health benefits such as hypoglycemic and hypolipidemic action, and antioxidant properties (OsorioEsquivel et al ., 2011).

The liver play a very important functions: it processes many of the products that are released into the blood stream (e.g. glucose derived from glycogenesis, plasma proteins and urea), it secretes bile into the intestine to help absorb nutrient, it 
takes some of the clotting factors needed to stop bleeding from acute or injury, and it also stored several products in the parenchymal cells (e.g. glycogen, fat and fat soluble vitamins) (Lehman 2008), biotransformation and removing the xenobiotics from the body, of which alcohol and dietary toxins are particularly (Kebamo et al., 2015). Liver cirrhosis is the irreversible end result of fibrous scarring and hepatocellular regeneration, characterized by diffuse disorganization of the normal hepatic structure of regenerative nodules and fibrotic tissue (Conn and attebury, 1993). It is associated with prominent morbidity and mortality, and is induced by many factors, including chronic hepatitis virus infections, alcohol drinking and drug abuse. Chronic hepatitis can have autoimmune, viral, metabolic, or medicine or toxin causes. The most common causes of chronic hepatitis are hepatitis B, hepatitis $\mathrm{C}$, and autoimmune hepatitis. Other causes are druginduced liver disease, metabolic diseases (Kathleen-Mahan, et al. 2012).
The kidneys are two beanshaped organs in the renal system. They help the body pass waste as urine. They also help filter blood before sending it back to the heart. Chronic kidney disease (CKD) usually gets worse slowly, and symptoms may not appear until your kidneys are badly damaged. In the late stages of CKD, as you are nearing kidney failure, you may notice symptoms that are caused by waste and extra fluid building up in your body (Stephens, 2018)

$\mathrm{CCl} 4$ is a widely used industrial solvent and it is the best-characterized animal model of xenobiotic-induced, oxidative stress-mediated hepatotoxicity (Hung et al., 2012). CCl4 induces the production of several types of reactive effect such as reactive metabolites, reactive oxygen species (ROS), inflammatory reaction, imbalance between cellular damage and protective responses and thereby causing liver injury (Xuan et al., 2015 and Tada, et al., 2003).

The present study was designed to investigate some 
parameters of the chemical composition of prickly pear peels and the effect of their nutritional status on liver and renal injury by $\mathrm{CCl}_{4}$.

\section{MATERIALS \& METHODS}

\section{Materials:}

- Prickly pear peels purchased from local market in Cairo city.

- Casein, vitamins, minerals, carbon tetra chloride (CCI4), methionine, kits and choline chloride were purchased from El-Gomhoreria Company.

- Oil and starch were obtained from local market in Cairo city. Paraffin oil obtained from pharmacy for dilution during the induction.

- Animals: Thirty healthy adult male albino rats "Sprague Dawley strain" weighing $165 \pm 5 \mathrm{~g}$ obtained from the animal colony, Helwan Farm, Vaccine and Immunity Organization, Helwan Governorate, Egypt.

- The standard diet prepared as described by Reeves et al., (1993).

\section{Methods:}

- Analytical methods:
The prepared samples were subjected to the chemical analysis moisture, protein and ash by the methods described by A.O.A.C. (1990). Total carbohydrates were determined using the method described by James (1995).

\section{- Biological experiment:}

Thirty healthy adult male albino rats were kept in single wire cages with wire bottoms under hygienic conditions. Feed and water were provided adlibitum and checked daily and was approved by the experiments animal unit- National Nutrition Institute.

\section{- Experimental design:}

Rats were fed on standard diet for one week for adaptation then; they were divided into two groups. The first group (6 rats) fed on standard diet only as a negative control group (C-). The second group (24 rats) was injected by Carbon tetrachloride (CCI4) was $10 \%$ liquid solution according to Passmore and Eastwood (1986). Rats were subcutaneously injected with (CCI4) dissolved in paraffin oil $(50 \% \mathrm{v} / \mathrm{v})$ at $2 \mathrm{ml} / \mathrm{kg} \mathrm{BW}$, twice a week for two weeks to induce the damage in liver. The 
hepatitis rats group was divided into four subgroups (6 rats / each) the first subgroup was continued to be fed on basal diet and considered as positive control $(\mathrm{C}+)$. Subgroups treated $(\mathrm{G} 1, \mathrm{G} 2$ and $\mathrm{G} 3$ fed on basal diet containing 5, 10 and $15 \%$ prickly pear peel respectively.

At the end of the experimental period (four weeks), the animals were sacrificed under ether anesthesia and blood samples were collected in dry centrifuge tubes from hepatic portal vein.

\section{Biological evaluation:}

Feed intake (FI); body weight gain (BWG) and Feed efficiency ratio $(F E R)$ :

Animals and feed were weighed twice a week. At the end of experiment feed intake and body weight gain calculated as a mean \pm SE for each group.

$\mathrm{BWG}=$ Final weight $(\mathrm{g})-$ Initial weight $(\mathrm{g})$

Feed efficiency ratio (FER):

Calculated as a follows:

FER = Body weight gain (g) /

Feed intake (g) during experimental period
Liver and kidney relative weight $=$ weight of organs g / Final weight of rat $\mathrm{g}$ X 100

\section{Biochemical Analysis:}

AST and ALT activities were measured according to method described by Reitman and Frankel (1957). Creatinine was determined according to the method described by Bohmer (1971). Urea was determined according to the method described by Patton and Crouch (1977).

\section{Histopathological study:}

Liver and kidney of the scarified rats were dissected, the fixed specimens were then trimmed, washed and dehydrated in ascending grades of alcohol. The tissue specimens were cleared in xylene, embedded in paraffin, sectioned at 4-6 microns thickness, stained with Hematoxylen and Eosin ( $\mathrm{H}$ and $\mathrm{E})$ and then studied under an electronic microscope according to (Carleton, 1979).

\section{Statistical analysis:}

All the obtained data were statistically analyzed by SPSS computer software. The calculated 
occurred by analysis of variance ANOVA and follow up test LSD (Artimage and Berry 1987).

\section{RESULTS \& DISCUSSION}

Prickly pear peel used in this study was chemically analyzed for its content of protein, moisture, ash, carbohydrates, fat and fiber. Results in table (1) showed that, prickly pear peel had a high level of protein and carbohydrates $15.5 \%$ and 42.29\%. Crude fiber was 14.3 $\mathrm{g} / 100 \mathrm{~g}$ which represents approximately nearly half of the recommended daily intake. Dietary fiber that is fundamental and intact in fiber-rich foods (e.g., fruits, vegetables, legumes, whole grains) is widely recognized to have beneficial effects on health when consumed at recommended levels $(25 \mathrm{~g} / \mathrm{d}$ for adult women, $38 \mathrm{~g} / \mathrm{d}$ for adult men) (McRorie 2015). Kerns (2008) reported that prickly pears are a good source of soluble fiber in the form of pectin, as well as the insoluble fibers cellulose and lignin. A diet rich in soluble fiber may help control blood cholesterol levels and decrease the risk of diabetes. Insoluble fiber intake can regulate bowel movements and may lower your risk of digestive disorders such as colon cancer. Apparent also, from the same table that Ash content was 11.2 as a measure of the total amount of minerals present within a food. Tremblay, (2017) indicated that prickly pear had an impressive mineral content. It provides a considerable amount of copper percent of your daily intake recommendation, copper supports your immune system and aids in red blood cell growth. Also contains 40 percent of the daily magnesium intake for women and 30 percent for men. Magnesium plays a key role in activating enzymes, while. Prickly pear also provides small amounts of potassium and calcium. Moisture value was in agreement with Cerezal and Duarte 2005, who demonstrated that the moisture content of fresh and dried PPPs was 80.17 and $18.50 \%$, respectively. 
Table (2) showed that feed intake was varied with non-significant differences. The body weight gain was $39.40 \pm$ $5.08 \mathrm{~g}$ for negative control group and decreased gradually and significantly in, 2and 3, subgroups and positive control group respectively. While subgroup 1 was the highest value for body weight gain and feed efficiency ratio. These results may due to which group fed 5\% prickly pear peel with lower soluble and insoluble fibers than other group. Results are compatible with Bisson et al., (2010) who suggested that Opuntia ficusindica intake can lead to reductions in body weight via dieresis and a good source of soluble fiber as pectin; insoluble fibers cellulose and lignin.

Table (3) demonstrated the effect of feeding prickly pear peels on liver and kidney relative weight. The values of liver relative weight was $2.5 \pm 0.2 \mathrm{~g}$ for negative control while positive control group was $2.9 \pm 0.1$, and decreased gradually for subgroups 1, and 2 compared with positive control but subgroup 3 was the same weight. The negative control kidney weight was $0.62 \pm 0.04 \mathrm{~g}$; there is no significant difference between negative control and all other groups. Prickly pear peels was tested in this study for its ameliorating effect to $\mathrm{CCl} 4$ induced hepatic injury in male rats through assessment of body weight, liver weight. These results coincide with those of Uemitsu and Nakayoshi (1984) who suggested no effect of oral $\mathrm{CCl} 4$ on body weight gain and liver weight.

High levels of ALT and AST in blood can be a sign of liver damage. The effect of feeding prickly pear peels on liver enzymes was shown in table (4). The positive control group had the highest value of AST and ALT with significantly compared negative control and treated groups. Group 3 which fed $15 \%$ from prickly pear peels had value is close to the value of the negative control group. These results are harmonious with Mohamed et al.,(2005) who reported that phenolic compounds sources (such as in 
Opuntia) have reduced the increase in serum AST and ALT. Flavones glycosides in prickly pear peels was reduced the elevated levels of the serum enzymes: GOT, GPT and ALP (Singab et al., 2005). Injected rat by $\mathrm{CCI}_{4}$ caused an increase of AST and ALT (Riad, 2014 and Elbanna, 2014). El-Nashar (2007) showed that the treatment with flavonoids were able to suppress the elevation of AST and ALT, reduce the damage of hepatocytes in vitro and exhibited strong antioxidant activity against reactive oxygen species (ROS) in vitro. Also Djerrou et al., (2015) concluded that Opuntia ficus-indica aqueous extract at a dose of $2 \mathrm{~mL} / \mathrm{kg}$ exerted a hepatoprotective effect against carbon tetrachlorideinduced toxicity in rats at least by decreasing AST activity.

The effect of feeding prickly pear peels on kidney function was illustrated in Table (5). Concerning creatinine, negative control group showed a level $0.83 \pm 0.02 \mathrm{mg} / \mathrm{dl}$, while positive control group showed a level $1.3 \pm 0.1 \mathrm{~g} / \mathrm{dl}$ with significant differences. Treated subgroups (1,2 and3 ) showed statistical difference between these subgroups and negative control group, but its showed a lower values than positive control group and normal group with significant differences. Urea value was significant differences between negative control group and treated subgroups with positive group. Korkmaz and Kolankaya (2009) found that ascorbic acid in male rats with renal ischemia - reperfusion injury exerts renoprotective effects which may be due to radical scavenging with antioxidant activities. In other study by Galati et al., (2003) who investigated the diuretic effect of a $15 \%$ extract from flowers, fruits, and peeled cladodes of O.ficus-indica on a rat model. Peeled cladodes showed the highest diuretic effect while urea level in blood urea and urine remained unchanged.

\section{Histopathological examination:}

- Histopathological examination of liver:

Microscopically examination of rat's livers from negative, 
positive and treated groups were revealed in figure (1). These observations correspond with Elgawish et al., (2015) who reported that $\mathrm{CCl}_{4}$ treated group revealed extensive liver injuries characterized by moderate to severe hepatocellular hydropic degeneration, necrosis, fibrosis and mononuclear inflammatory leukocyte infiltrations.

\section{- Histopathological} examination of kidneys: Microscopically, kidneys of rat from all groups were showed in figure (2). These results correlated with Karthikeyan et al., (2012) who found there are morphological changes in cortical tubules, such as dilated and flattened epithelial cells. Several research showed extensive cortical damage and focal glomerular necrosis were observed in $\mathrm{CCl}_{4}$ challenged group (Doi et al., 1991). Interstitial inflammatory cell infiltration was also seen in the $\mathrm{CCl}_{4}$ group (Ozturk et al., 2003; Ogeturka et al., 2005), whereas, the group of rats pretreated with extract reversed the $\mathrm{CCl}_{4}$-induced nephrotoxicity; it shows the glomeruli were normal and sparse tubular changes were observed. In this group, the affected tubules showed vacuolization, dilation, and a few cell detachments.

\section{CONCLUSION:}

$\mathrm{CCl}_{4}$-induced liver and kidney toxicity might be related to oxidative damage. Prickly pear peels has a beneficial effect decreasing liver enzyme and kidney parameters. Further studies are needed to clarify the precise mechanisms of prickly pear peels action.

\section{REFERENCES:}

AOAC (1990):

Association of Official Analytical Chemists. Official Methods of Analysis of Association of Official Analytical Chemists. Washington, D.C., USA.

\section{Artimage GY and Berry WG} (1987):

Statistical Methods 7th Ed. Ames, Iowa Stata University Press, 39-63. 
Bisson JF; Daubie S; Hidalgo S; Guillemet $D$ and Linares

E. (2010):

Diuretic and anti- oxidant effects of Cacti-Nea, a dehydrated water extract from prickly pear fruit, in rats. Phytother Res; 24:587-94.

Bohmer HBUM (1971):

Micro-determination of creatinine. Clin. Chem. Acta, 32: $81-85$.

\section{Carleton H (1979):}

Histological Technique, 4 th Ed., London, Oxford University Press, New York, Toronto.

\section{Cerezal P and Duarte G (2005):}

Sensory influence of chemical additives in peeled cactus pears (Opuntia Ficus-indica (L.) Miller) in syrup conserved by combined methods .Journal of the professional Association for Cactus Development 6, 61-83
Chougui N; Djerroud N; Naraoui F; Hadjal S; Aliane K; Zeroual B and Larbat R (2015) :

Physicochemical

properties and storage stability of margarine containing Opuntia ficusindica peel extract as antioxidant. Food Chem. $15 ; 173: 382-90$.

Conn HO and Atterbury CE(1993):

Diseases of the Liver Vol. 2 (eds. Schiff, L. \& Schiff, E.R.) 875-941 (J.B.

Lippencott, Philadelphia)

Djerrou Z; Maameri Z; Halmi S, Djaalab H, Riachi F, Benmaiza $L$ and Hamdipacha $Y$ (2015):

Hepatoprotective, Effect of Opuntia Ficus-Indica Aqueous Extract against Carbon TetrachlorideInduced Toxicity in rats. Journal of Biological Sciences. 15; 2, 36-41

Doi K; Kurabe S; Shimazu N and Inagaki M (1991):

Systemic histopathology of rats with $\mathrm{CCl} 4$-induced 
hepatic cirrhosis,"

Laboratory Animals, vol.

25 , no. 1, pp. 21-25,
Home Economics,

Minoufiya University,

Shebin El-Kom, Egypt.

\section{Elbanna SM (2014):}

Phytochemicals

in

artichoke

(Cynara

Scolymus, L.) and their effects on liver disorder initiation by carbontetrachloride. M.Sc. Theses, Faculty of Home Economics, MenoufiaUniversity.

Elgawish RAR; Abdel Rahman H G; and Abdelrazek HMA (2015):

Green tea extract attenuates $\mathrm{CCl} 4$-induced hepatic injury in malehamsters via inhibition of lipid peroxidation and p53mediatedapoptosis

Toxicology Reports 2 1149-1156

El-Nashar NG (2007):

Development of primary liver cell culture from fish as a valuable tool in nutrition and biotechnology research. Ph.D. Thesis, Faculty of
Galati EM; Monello MR; Gluffrida DG; Miceli N; Pergolizzi $S$ and Taviano $M$ (2003) :

Chemical characterization and biological effects of Sicilian Opuntia Ficusindica (L.) fruit juice : antioxidant and anticarcinogenic activity : Journal of Agricultural and Food Chemistry 51,49034908.

\section{Hung GL; Lee P; Chang H; Chien $H$ and Lee CK (2012): \\ Green \\ tea \\ extract supplementation ameliorates CCl4-induced hepatic oxidative stress, fibrosis, and acute-phase protein expression in rat, J. Formos. Med. Assoc. 111, 550-559}

\section{James CS (1995):}

Analytical chemistry of foods. Publ. Blackie Academic and Professional, an imprint of Chapman and Hall, Wester Cleddens Road, Bishop 
Briggs, Glasgow G642 NZ.

Karthikeyan R; Anantharaman P; Chidambaram N; Balasubramanian $T$ and Somasundaram ST (2012):

Padina boergessenii ameliorates carbon tetrachloride induced nephrotoxicity in Wistar rats Journal of King Saud University - Science 24, 227-232

\section{Kathleen M L; Escott-Stump S;} Janice $L$ and Raymond $J$

(2011):

"Krause's" Food \& Nutrition Therapy Care Process $13^{\text {th }}$ ed . Elsevier/ Saunders

Kebamo S; Shibiru $T$ and Bekesho G (2015):

The Role of

Biotransformation in Drug

Discovery and

Development 6 J Drug

MetabToxicol: 5: 1-13.

Kerns MM (2008):

Plant Foods for Human

Nutrition: Phenolic

Composition, Antioxidant
Capacity and In Vitro Cancer Cell Cytotoxicity of Nine Prickly Pear (Opunia spp.) Juices

Korkmaz A and Kolankaya D (2009):

The protective effects of ascorbic acid against renal ischemia - reperfusin injury in male rats. Renal Faliure 31, 36-43.

Lehman EM (2008):

Dynamics of liver disease in Egypt: Shifting paradigms of a complex etiology, PhD Thesis, The University of Michigan, MI.

McRorie, J (2015):

Evidence-Based Approach to Fiber Supplements and Clinically Meaningful Health Benefits, Part 1What to Look for and How to Recommend an Effective Fiber Therapy, Nutrition Today, Volume 50, Number 2,

Milán-Noris AK; ChavezSantoscoy RA, Olmos- 
Nakamura A; Gutiérrez-Uribe JA and Serna-Saldívar SO (2016):

An Extract from Prickly

Pear Peel (Opuntia ficusindica) Affects Cholesterol Excretion and Hepatic Cholesterol Levels in Hamsters Fed Hyperlipidemic

Diets.Current Bioactive Compounds, Vol. 12, No. 1

Mohamed A; Ali Hassan A; Hamamy $M$ and Abdel- Satter $E$ (2005):

Antioxidant and hepatoprotective effect of Eucalyptus maculate. Med. Sci. Monit., 11(11):42631.

Ogeturka M; Kusa I; Colakoglub N; Zararsiza I; Ilhanc $\mathbf{N}$ and Sarsilmaz $M$ (2005):

Caffeic acid phenethyl ester protects kidneys against carbon tetrachloride toxicity in rats. J. Ethnopharmacol. 97, 273-280.
Osorio-Esquivel O; Alicia-Ortiz Moreno; Álvarez, VB; DorantesÁlvarez L; Giusti MM (2011):

Phenolics, betacyanins and antioxidant activity in Opuntia joconostle fruits. Food Res. Int,44, 21602168.

Ozturk F; Ucar M; Ozturk CI; Vardi N and Batcioglu K (2003): Carbon tetrachlorideinduced nephrotoxicity and protective effect of betaine in Sprague-Dawley rats. Urology 62 (2), 353-356.

\section{Passmore R and Eastwood MA (1986): \\ Human Nutrition and Dietetics Eight Editions, Longman Group UK LTD. Churchill}

Livingstone.

Patton $C$ and Crouch SR (1977):

Determination of urea. Anal. Chem. 149:464-469.

Reeves PG; Nielson FH and Fahmy GC (1993):

Reports of the American Institute of Nutritio; adhoc willing committee on 
reformulation of the AIN 93.Rodent Diet .J. Nutri, (23):1939-1951.

Reitman $S$ and Frankel $S$ (1957):

A color metric method for the determination of serum glutamic oxaloacetic and glutamic pyruvic transaminases. Am. J. Clin. Path, 28: $56-63$.

Riad MA (2014):

Utilization of vegetable wastes for treatment of hepatointoxication in CCI4 albino rats. M.Sc. Theses, Faculty of Home Economics, Menoufia University.

Singab ANB; Youssef DTA; Noaman $E$ and Kotb $S$ (2005):

Hepatoprotective effect of flavonol glycosides rich fraction from Egyptian vicia calcarata Desf against CCI4-induced liver damage in rats, Arch. Pharm. Res.28:791-798.

Stephens C (2018):
Kidney overview, National Kidney Foundation, HON code principles of the Health on the Net Foundation

Tada S; Nakamoto N; Kameyama K; Tsunematsu S; Kumagai N; Saito $H$ and Ishii $H$ (2003):

Clinical usefulness of edaravone for acute liver injury, J. Gastroenterol. Hepatol. 18 (2003) 851-857

Tremblay S (2017): Prickly Pear Nutritional Values. MSC.

\section{Uemitsu $\mathbf{N}$ and Nakayoshi $H$} (1984):

Evaluation of liver weight changes following a single oral administration of carbon tetrachloride in rats, Toxicol. Appl. Pharmacol. 75 (1) 1-7.

\section{Xuan J; Chen S; Ning B;} Tolleson WH; and GuiL (2015):

Development of Hep G2derived cells expressing cytochrome P450 for assessing metabolismassociated drug induced 
Evaluation of feeding prickly pear peels to ameliorate the effect of Carbon tetrachloride in rats

Hanady G Sheha and Hoda M El Gezery

liver toxicity, Chem Biol Interact. 2797 (15) 300880

Yeddes N, Chérif JK and Ayadi TM (2014):

Comparative study of antioxidant power, polyphenols, flavonoids and betacyanins.Pak J Biol Sci.; 17(5):650-8.
Comparative Study of Antioxidant Power, Polyphenols, Flavonoids and Betacyanins of the Peel and Pulp of Three Tunisian Opuntia Forms. Antioxidants (Basel), Apr 19; 2(2):37-51.

Yeddes N, Chérif JK, Guyot S,

Sotin H, and Ayadi MT (2013): 
Tables (1): Chemical Composition of prickly pear peels (g/100g) dried

\begin{tabular}{|l|c|}
\hline Samples & $\begin{array}{c}\text { prickly pear } \\
\text { peels }\end{array}$ \\
\hline Protein & 15.5 \\
\hline Carbohydrates & 42.3 \\
\hline Ash & 11.2 \\
\hline Fiber & 14.3 \\
\hline Fat & 5.7 \\
\hline Moisture & 11.0 \\
\hline
\end{tabular}

Table (2): Effect of Feeding Prickly Pear Peels on Body Weight Gain, Feed Intake and Feed Efficiency Ratio

\begin{tabular}{|c|c|c|c|c|c|}
\hline $\begin{array}{c}\text { Groups } \\
\text { parameters }\end{array}$ & C- & $\mathrm{C}+$ & subG1 & subG2 & subG3 \\
\hline $\begin{array}{ll}\text { BWG } & \text { g/ } \\
\text { period }\end{array}$ & $\begin{array}{l}39.2 \quad \pm \\
1.9^{\mathrm{b}}\end{array}$ & $\begin{array}{ll}19.0 & \pm \\
0.6^{\mathrm{d}} & \end{array}$ & $\begin{array}{ll}49.2 & \pm \\
2.1^{\mathrm{a}} & \end{array}$ & $\begin{array}{ll}30.3 & \pm \\
1.3^{\mathrm{c}} & \end{array}$ & $\begin{array}{ll}22.0 & \pm \\
1.0^{\text {d }} & \end{array}$ \\
\hline $\begin{array}{l}\text { Feed intake } \\
\text { g/day }\end{array}$ & $\begin{array}{l}12.9 \quad \pm \\
0.38^{\mathrm{a}}\end{array}$ & $\begin{array}{l}12.7 \\
0.03^{\mathrm{a}}\end{array}$ & $\begin{array}{l}12.1 \pm \\
0.35^{\mathrm{a}}\end{array}$ & $\begin{array}{l}12.6 \pm \\
0.33^{\mathrm{a}}\end{array}$ & $\begin{array}{l}12.4 \\
\mathbf{0 . 0 3}^{\mathrm{a}}\end{array}$ \\
\hline $\begin{array}{l}\text { Feed } \\
\text { efficiency } \\
\text { ratio }\end{array}$ & $\begin{array}{l}0.11 \\
0.01^{b}\end{array}$ & $\begin{array}{l}0.05 \\
0.02^{d}\end{array}$ & $\begin{array}{l}0.14 \pm \\
0.02^{\mathrm{a}}\end{array}$ & $\begin{array}{l}0.09 \\
0.03^{\mathrm{c}}\end{array}$ & $\begin{array}{ll}0.06 & \pm \\
0.01 & \end{array}$ \\
\hline
\end{tabular}

L.S.D. at level 0.05 (Each value in the table is the mean and standard deviation of five replicates means in the same row with different letters are significantly different $(P \leq 0.05)$ 
Table (3): Effect of Feeding Prickly Pear Peels on some Organ's Relative Weight $(\mathrm{g})$

\begin{tabular}{|c|c|c|c|c|c|}
\hline $\begin{array}{l}\text { Groups } \\
\text { Parameters }\end{array}$ & C- & $\mathrm{C}+$ & SubG1 & SubG2 & $\begin{array}{l}\text { SubG } \\
3\end{array}$ \\
\hline $\begin{array}{l}\text { Liver relative } \\
\text { weight }\end{array}$ & $\begin{array}{ll}2.5 & \pm \\
0.2^{\mathrm{a}} & \end{array}$ & $\begin{array}{l}2.9 \pm \\
0.1^{\mathrm{a}}\end{array}$ & $\begin{array}{l}2.7 \\
0.1^{\mathrm{a}}\end{array}$ & $\begin{array}{l}2.8 \quad \pm \\
0.14^{\mathrm{a}}\end{array}$ & $\begin{array}{l}2.9 \pm \\
0.15^{\mathrm{a}}\end{array}$ \\
\hline $\begin{array}{l}\text { Kidney relative } \\
\text { weight }\end{array}$ & $\begin{array}{l}0.62 \pm \\
0.04^{a}\end{array}$ & $\begin{array}{l}0.56 \pm \\
0.04^{a}\end{array}$ & $\begin{array}{l}0.54 \\
0.02\end{array}$ & $\begin{array}{l}0.55 \pm \\
0.02^{\mathrm{a}}\end{array}$ & $\begin{array}{l}0.59 \pm \\
0.01^{\mathrm{a}}\end{array}$ \\
\hline
\end{tabular}

L.S.D. at level 0.05 (Each value in the table is the mean and standard deviation of five replicates means in the same row with different letters are significantly different $(P \leq 0.05)$

Table (4): Effect of Feeding Prickly Pear peels on liver Enzymes

\begin{tabular}{|c|c|c|c|c|c|}
\hline $\begin{array}{l}\text { Groups } \\
\text { Parameters }\end{array}$ & C- & $\mathrm{C}+$ & SubG1 & SubG2 & SubG3 \\
\hline AST(U/L) & $\begin{array}{l}91.00 \quad \pm \\
4.8^{\mathrm{b}}\end{array}$ & $\begin{array}{l}132.7 \\
12.6^{\mathrm{a}}\end{array}$ & $\begin{array}{l}101.83 \pm \\
6.0^{\mathrm{b}}\end{array}$ & $\begin{array}{l}97.00 \\
4.03^{\mathrm{b}}\end{array}$ & $\begin{array}{ll}92.67 & \pm \\
7.3^{b} & \end{array}$ \\
\hline $\operatorname{ALT}(\mathbf{U} / \mathrm{L})$ & $\begin{array}{l}25.20 \\
1.8^{b}\end{array}$ & $\begin{array}{l}46.17 \\
3.5^{\mathrm{a}}\end{array}$ & $\begin{array}{l}30.50 \\
2.1^{b}\end{array}$ & $\begin{array}{l}26.38 \quad \pm \\
2.0^{b}\end{array}$ & $\begin{array}{l}22.57 \\
0.61^{\text {c }}\end{array}$ \\
\hline
\end{tabular}

L.S.D. at level 0.05 (Each value in the table is the mean and standard deviation of five replicates means in the same row with different letters are significantly different $(P \leq 0.05)$ 
Table (5) Effect of Feeding Prickly Pear Peels on kidney function

\begin{tabular}{|c|c|c|c|c|c|}
\hline $\begin{array}{l}\text { Groups } \\
\text { Parameters }\end{array}$ & C- & $\mathrm{C}+$ & SubG1 & SubG2 & SubG3 \\
\hline $\begin{array}{l}\text { Creatinine } \\
\mathrm{mg} / \mathrm{dl}\end{array}$ & $\begin{array}{l}0.83 \\
0.02^{\mathrm{b}}\end{array}$ & $\begin{array}{l}1.3 \quad \pm \\
0.1^{\mathrm{a}}\end{array}$ & $\begin{array}{l}0.63 \pm \\
0.03^{\mathrm{bc}}\end{array}$ & $\begin{array}{l}0.60 \pm \\
0.03^{\mathrm{c}}\end{array}$ & $\begin{array}{ll}0.58 & \pm \\
0.06^{c}\end{array}$ \\
\hline $\begin{array}{l}\text { Urea } \\
\mathrm{mg} / \mathrm{dl}\end{array}$ & $\begin{array}{l}22.2 \pm \\
1.6 \mathrm{~b}\end{array}$ & $\begin{array}{l}39.4 \pm \\
1.6 \mathrm{a}\end{array}$ & $\begin{array}{l}25.9 \pm \\
0.9 \text { b }\end{array}$ & $\begin{array}{l}24.2 \pm \\
1.7 b\end{array}$ & $\begin{array}{l}22.4 \pm 2.1 \\
\text { b }\end{array}$ \\
\hline
\end{tabular}

L.S.D. at level 0.05 (Each value in the table is the mean and standard deviation of five replicates means in the same row with different letters are significantly different $(P \leq 0.05)$ 


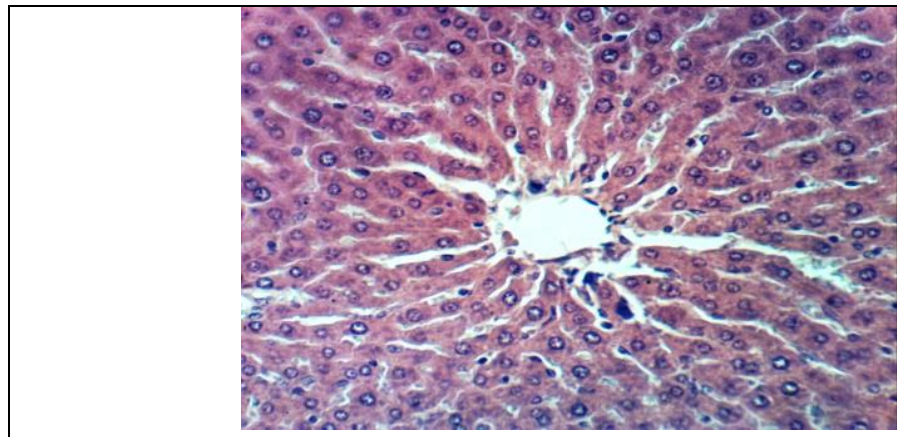

Fig. (A): Liver of rat from group control negative showing the normal histological structure of hepatic lobule ( $\mathrm{H} \& \mathrm{E} X \mathrm{400})$.

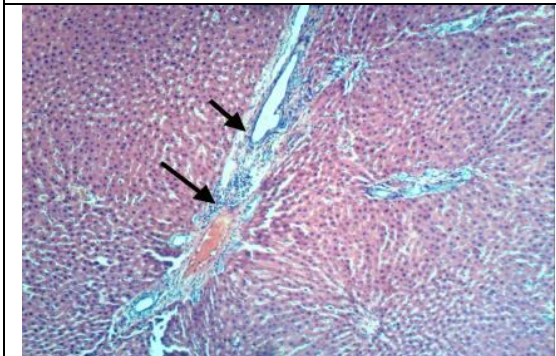

Fig. (B): Liver of rat from group control positive showing hyperplasia of epithelial lining bile duct, fibroplasia in the portal triad and portal infiltration with inflammatory cells $(\mathrm{H} \& \mathrm{E}$ X 100).

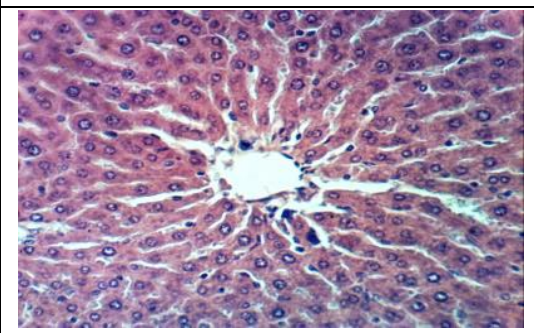

Fig. (D): Liver of rat from group 2(10\% PPP) showing the normal histological structure of hepatic lobule (H \& E X 400).

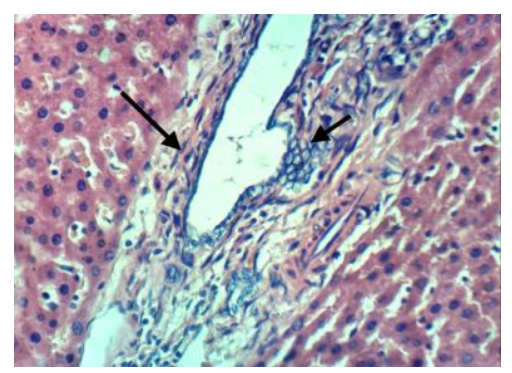

Fig. (C): Liver of rat from group 1 (5\% PPP) showing hyperplasia of epithelial lining bile duct, fibroplasia in the portal triad $(\mathrm{H}$ \& E X 400).

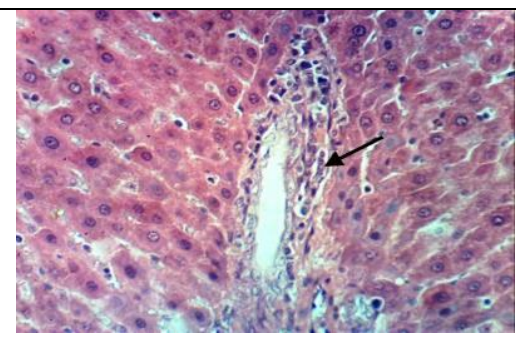

Fig. (E): Liver of rat from group $3 \quad(15 \% \quad \mathrm{PPP})$ showing fine strands of fibroblasts in the portal triad (H \& E X 400).

Figure (1) Liver of rat from negative, positive control and treated groups 


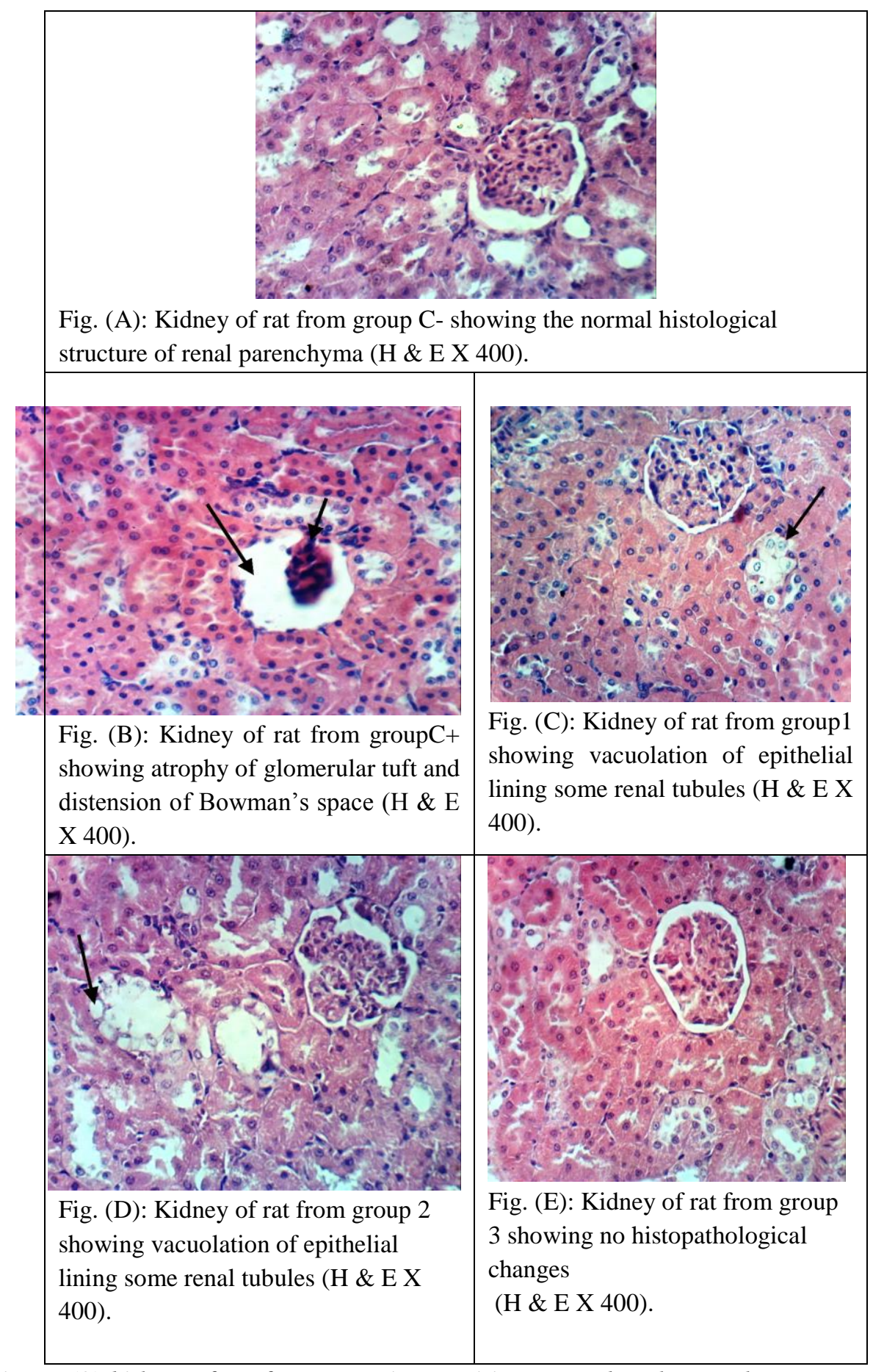

Figure (2) kidney of rat from negative, positive control and treated groups 


\section{تقيميم تثاول قشيور التين ألثوكي لتحسين تأثير رابع كلوريد الكربون في الجرذان \\ هنادى جابر شيحة ـ هدى مسعود الجزيرى

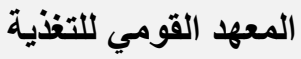

الملخص العربي

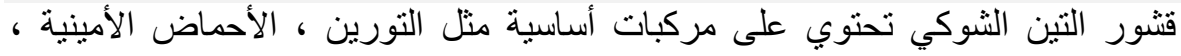

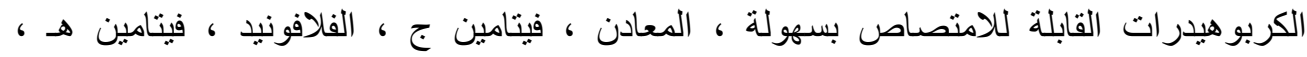

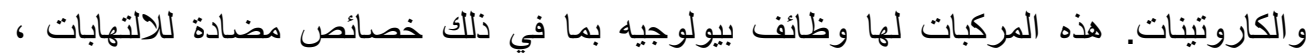

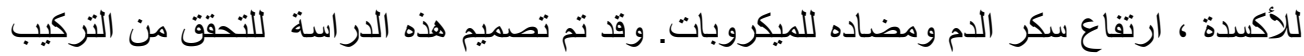

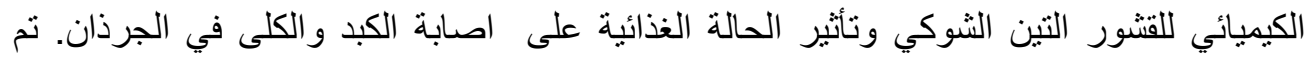
تقسيم ثلاثين من ذكور الجرذان البالغين سلالة السبر اجو داولي إلى مجمو عتين رئيسيتين تغذئت على على

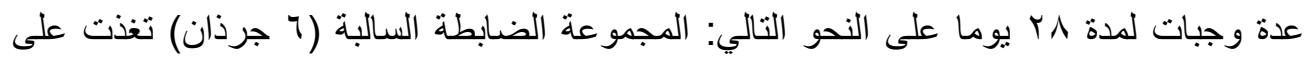

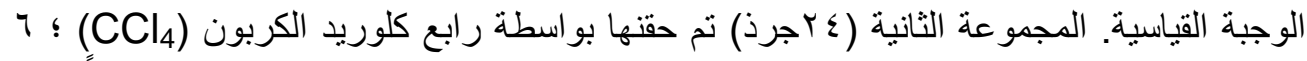

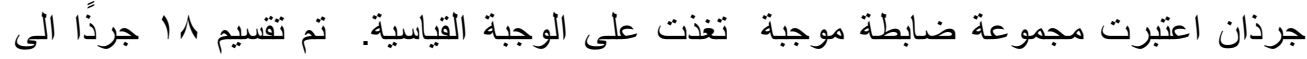

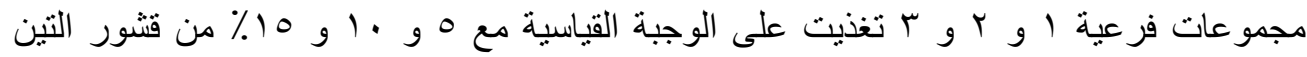

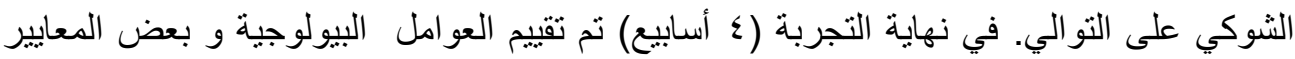

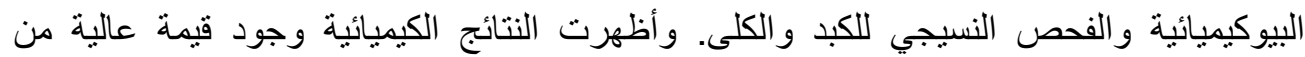

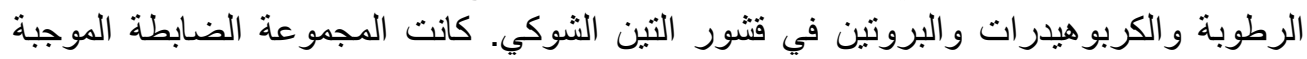

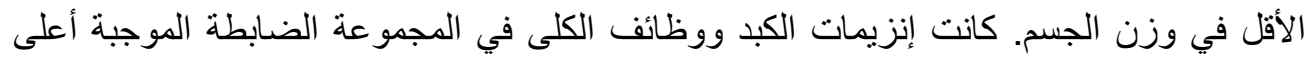
بقيم معنويه من المجموعة الضابطة السالبة ومجموعات المعالجة. قشر التين الثوكي خفف من تأثير CCl 4

$$
\text { الكلمات المفتاحية: شتور التين الثوكي ـ الكبد ــ الكلى ــ رابع كلوريد الكربون }
$$

